\title{
The Community Structure of Phytoplankton in Seagrass Ecosystem and its Relationship with Environmental Characterstics
}

\author{
${ }^{\square}$ Gede Iwan Setiabudi $^{1}$, Dietriech G. Bengen ${ }^{2}$, Hefni Effendi $^{3}$, Ocky Karna Radjasa ${ }^{4}$ \\ DOI: $10.15294 /$ biosaintifika.v8i3.6549 \\ ${ }^{1}$ Faculty of Fisheries and Marine Science, Bogor Agricultural University, Indonesia \\ ${ }^{2}$ Department Marine Science and Technology, Faculty of Fisheries and Marine Science, Bogor Agricultural \\ University, Indonesia \\ ${ }^{3}$ Department Aquatic Resources Management, Faculty of Fisheries and Marine Science, Bogor Agricultural \\ University, Indonesia \\ ${ }^{4}$ Faculty of Fisheries and Marine Science, Diponegoro University, Indonesia
}

\section{History Article}

Received 12 June 2016 Approved 27 July 2016 Published 24 December 2016

\section{Keywords:}

Community structure; Plankton; Environment characteristics: Pegametan Bay

\begin{abstract}
The aimed of this study was to determine the plankton communities and its relationship with the chemical and physical condition in seagrass ecosystem at Pegametan Bay. The composition and abundance of plankton were observed in the sea water underneath the surface and were identified based on the guideline of Illustration of the Marine Plankton of Japan. The water quality was measured in situ using WQC HI 9829. The water sample was measured using closed reflux spectrometry for COD, TOC analyzer for DOC and APHA 2102 (4500) method for Nt and Pt. There are 27 species of plankton identified, which can be classified into three groups. Diatom group consists of 18 species with a $74.56 \%$ abundance. The nonlitoral group consists of 6 species with a $23.35 \%$ abundance. Moreover, dinoflagellate group consist of 3 species with a $2.09 \%$ abundance. An abundance of plankton greater than $10^{4}$ cell. $\mathrm{L}^{-1}$ was found in diatome group (Nitzschia sp., Thalassiosira sp., Chaetoceros sp., Flagillaria sp., Thalassiothrix sp., and Melosira sp.) and non-litoral group (Oscillatoria sp. and Spirogyra sp.). The abundance of those species indicated the algae bloom phenomenon. Dinophysis sp. was also identified, which was harmful algal blooms.
\end{abstract}

\section{How to Cite}

Setiabudi, G. I., Bengen, D. G., Effendi, H., \& Radjasa, O. K. (2016). The Community Structure of Phytoplankton in Seagrass Ecosystem and its Relationship with Environmental Characterstics. Biosaintifika: Journal of Biology \& Biology Education, 8(3), 257-269.

(C) 2016 Universitas Negeri Semarang $\bowtie$ Correspondence Author:

J1. Rasamala, Kampus IPB Darmaga, Bogor 16680

E-mail: insetiabudi@gmail.com
p-ISSN 2085-191X

e-ISSN 2338-7610 


\section{INTRODUCTION}

Seagrass is one of the important ecosystems at the tropical coastal region. The degradation of the seagrass ecosystem has always been followed by algae blooms (Kennish, 2010). If the condition is good, the abundance of planktonic algae is low. In the previous study by Sridhar et al. (2010), the abundance of planktonic algae was only approximately $5.5 \times 10^{4} \mathrm{cell}^{\mathrm{L}} \mathrm{L}^{-1}$, even though the concentration of thenutrition tended to be high. It was assumed that the high assimilating ability of the algae ecosystem causing the high consuming rate of nutrition in the pool. The study showed that biomass and the planktonic algae primary productivity in the seagrass ecosystem were inversely proportional to $\mathrm{pH}$, nitrate concentration, temperature and other hydrobiological parameters (Sridhar et al., 2010).

There is a complex interaction between the planktonic algae population with the Zoostera noltii seagrass species. It was reported that there $\mathrm{s}$ an allelopathic substance which could impede the growth of planktonic algae. However, it was not explained whether the substance was produced by seagrass or other organisms, like the symbionts. Besides, a large quantity of nutrient intake, grazing activity and the interaction between the water column flows with the sediments were also the factors that contributed to the growth of planktonic algae (de Witt et al., 2012).

Pegametan Bay is a mariculture region, which is located in the western part of Buleleng Regency, Bali. Barrier reef covers the region in the north part and sand dune covers in the west part, whereas the east side is relatively open. The sand dune that exists in the western part of the Bay is an ideal habitat for the seagrass ecosystem naturally . Besides, it is located in the tidal zone, the waters are also shallow, ranging from 0 to 5 meters in depth (Setiabudi et al., 2007; Hanafi, 2004).

The bay's enclosed topography is an ideal location for mariculture activities. The barrier reef and sand dune can hold waves and tides. Thus the water is calm. The loss resulting from the broken floating fish cages is small, and that is the main consideration in the mariculture business. Its activities conducted at the Bay are floating fish cages, pen culture, and sea cages. The commodities cultivated are grouper, barramundi, seaweed and decorative fish quarantine. The model business developed is mostly fish rearing (Hanafi, 2004).

High mariculture activities and large quantities of floating fish cages affected the condition of the waters of Pegametan Bay. High loading of feed loss, metabolism waste, mariculture process (such as fresh water for disinfection and the rubbish left by the workers), the condition of the bay that is closed resulted in high pollution (Price et al., 2015). Those are observed from the condition of the waters around the floating fish cages, which was consistently dark green. Such watercolor shows high turbidity as a result of a high plankton abundance. Unlike the area which has high seagrass density, the turbidity tends to be low.

In fact, the characteristics of seagrass influence the abundance of plankton in the water column (Marba et al., 2006). Its elatively high absorbing level makes the seagrass act as the competitor of plankton in absorbing the water nutrient. The condition of Pegametan Bay, which is relatively closed results in long retention time of the dissolved nutritions. Its particular phenomenon makes Pegametan Bay to be specific, where the structure of plankton community and its relationship with the chemical and physical condition of the waters can be observed.

The scope of this study covered three sections, namely, the characteristics of the environment, the variability of the plankton community in the water column and the influence of the environment on the variability of the plankton community at Pegametan Bay.

\section{METHODS}

The location of the research was Pegametan Bay, Gerokgak District, Buleleng Regency, Bali. This area is a small bay which has high mariculture activities. It is indicated by many floating fish cages for commercial fish rearing. In the western part of the bay, there is sand dune with shallow waters. At Pegametan Bay, there is seagrass habitat that grew quite well. The samples were collected in five spots; at the extended area of seagrass close to the barrier reef, the floating fish cages, and the seagrass.

The guideline entitled Seagrass Taxonomy and Identification Keys (Kuo \& den Hartog, 2006) was used as a reference in the identification process.

The water quality was measured at five spots of observation. The parameter measured in situ included salinity, temperature, turbidity, conductivity, DO, Oxidation-Reduction Potential (ORP) and $\mathrm{pH}$. The measuring instrument used was the Water Quality Checker (WQC) HI 9829. The measurement of the Chemical Oxygen Demand (COD) parameter was done by tak- 
ing $500 \mathrm{~mL}$ of seawater sample. The sample was analyzed at the Chemistry Laboratory at the Ganesha University of Education, using the closed reflux spectrometry method.

The types of nutrients measured were the total $\mathrm{N}(\mathrm{Nt})$, the total $\mathrm{P}(\mathrm{Pt})$ dan Dissolved Organic Carbon (DOC). The measurement was done by taking water sample that was $30 \mathrm{~cm}$ underneath the surface. The instrument used was the water sampler with $1 \mathrm{~L}$ volume. The sample was prepared using $\mathrm{H}_{2} \mathrm{SO}_{4}$ as much as $1 \mathrm{~mL} . \mathrm{L}^{-1}$ sample. The nutrient concentration was analyzed at the ProLing Laboratory of Bogor Agriculture University (IPB).

The composition and abundance of phytoplankton in the seagrass ecosystem were observed by taking the sea water that was underneath the surface. The water samples were taken in five stations. They ranged from the coral reef to the extended area of the of theseagrass, and around the mariculture activities. The instrument used was the Planktonet with an opening diameter of 30 $\mathrm{cm}$ and a mesh size of $30 \mu \mathrm{m}$. The planktonet was sunk until its opening was ranged at $10-30 \mathrm{~cm}$ beneath the water surface. Afterward, it was pulled by $30 \mathrm{~m}$. The planktonet was sunk because the water was collected during daytime from 11.00 am-02.00 pm. At those hours, planktons would float under the water surface to avoid the high intensity of the sunlight and water temperature. It was then pulled to collect the phytoplankton from the broader area and to increase the chance of collecting various species. The water sample was then placed in a bottle at the bottom part of the planktonet. Afterward, it was placed in HighDensity Polyethylene (HDPE) bottle, and $4 \%$ formalin was given as much as $1 \mathrm{~mL}$ in every 500 $\mathrm{mL}$ of sample. The sample was kept in a light proof container with a low temperature until it was identified.

The identification and the counting of the number of phytoplankton was done at the Plankton Laboratory of Research Centre of Oceanography (RCO), the Indonesian Institute of Science (LIPI). The guideline from Yamaji (1982) was used as a guidance to the identification process. In the preparation stage, the water sample was made to be homogeneous for 30 minutes at the shaker. After that, $1 \mathrm{~mL}$ of water was taken randomly and dropped into the object glass. Abundance is the number of individual phytoplankton per volume of water. The abundance of phytoplankton was determined based on the swipe method on the counting chamber glass. The abundance of phytoplankton was calculated based on the formula of Fachrul (2007). During the identification process, the enlargement ranged between $100 \times-$ $400 \times$. The observation was repeated three times to confirm the quantity. Afterward, the species and the abundance of each of them was identified.

$$
\mathrm{N}=\mathrm{n} \times\left(\frac{\mathrm{Vr}}{\mathrm{Vo}_{\mathrm{o}}}\right) \times\left(\frac{1}{\mathrm{Vs}_{\mathrm{s}}}\right)
$$

$\mathrm{N}=$ the number of cell (cell. $\left.\mathrm{L}^{-1}\right)$

$\mathrm{n}=$ the number of the cell which was identified $\mathrm{Vr}=$ the volume of the water which was filtered $\mathrm{Vo}=$ the volume of the water observed at the Counting chamber

Vs $=$ the volume of the water which was filtered (1)

Data were analyzed were phytoplankton community structure and its relation to the biophysical characteristics of the environment. The analytical tool used is a principal component analysis (PCA) and correspondence analysis (CA).

PCA is used to simplify the data. These techniques can transform data in a linear manner to form a new coordinate system with the maximum variant. In this study used to demonstrate the correlation between the parameters of salinity, temperature, turbidity, conductivity, DO, Oxidation-Reduction Potential (ORP), $\mathrm{pH}$, COD, and nutrients. This analysis will show that habitat-grouping determiner axes were optimum variables measured are projected. Bengen (2000) states that the PCA can be used to associate a descriptive role in quantitative limit within the limits of quantitative and qualitative. Correspondence analysis (CA) was used to transform data into a two-dimensional graph. In this study shows a breakdown of phytoplankton with CA, based on distribution at every station.

\section{RESULTS AND DISCUSSION}

\section{The types of seagrass at pegametan bay.}

Kingdom : Plantae

Divisio : Magnoliophyta (Angiosperms)

Class : Liliopsida

Sub-class : Alismatidae

Order : Alismatales

Family : Hydrocharitaceae

Genus : Enhalus

Species: Enhalus acoroides

Genus : Thalassia

Species: Thalassia hemprichii

Genus : Halophila

Species: Halophila ovalis

At the time of research investigation, there were three seagrass species identified at Pegametan Bay, namely, Enhalus acoroides, Thalassia hemprichii and Halophila ovalis (Figure 1, 2 and 3). 
They all belonged to the Hydrocharitaceae family, meaning that they all lived entirely in water. Seagrass was found in stations $1,3,4$ and 5. E. acoroides was found in all those stations, while $T$. hemprichii and $H$. ovalis were found merely in stations 3 and 4.

\section{The physical and chemical characteristics of the waters}

Pegametan Bay is an enclosed bay with high mariculture activities. There is barrier reef at its north side, laying from the east to the west, and quite vast sand dune at its west side, which lays from north to south, connecting the water with the land. Those structures make the bay shapes look like the letter $C$, as there is no barrier on the east side. The characteristics of the environment of the bay waters were marked by the physical and chemical parameters (Table 1). The physical conditions included the temperature which ranged from average $31.5^{\circ} \mathrm{C}$, the conductivity which was $43.6 \mathrm{mScm}$ and turbidity which was 3 FNU. The chemical conditions included average salinity which was around $30.40 \mathrm{PSU}$, DO of $5.42 \mathrm{ppm}$, COD of $75.72 \mathrm{mg} . \mathrm{L}^{-1}$, ORP of $192.82 \mathrm{mV}$ dan $\mathrm{pH}$ of 8.24 .

\section{The nutrient concentration of the waters}

The existence of nutrients was measured from the $\mathrm{Nt}$, the $\mathrm{Pt}$, and the DOC. The concentration of $\mathrm{Nt}$ tended to be equal in all stations; in the seagrass area (stations $3,4,5$ ), in the area close to the reef (station 1), in the relatively deep waters (station 2). The highest concentration occurred in station 5 , that is, in the location close to the floating fish cages which had a substrate with dense seagrass in it (Figure 4). The concentration of Pt was fluctuating; it tended to be low $(<0.05$ mg. $\left.\mathrm{L}^{-1}\right)$ in stations 1,2 and 4 and tended to be high in stations 3 nd 5 (Figure 5). The concentration of DOC in stations 1 and 2 was higher compared to that in stations 3,4 and 5 . The highest concentration of DOC occurred in the relatively deep waters, close to the floating fish cages, in the middle part of the bay. The lowest concentration occurred in the seagrass ecosystem close to the floating fish cages, at the southern part of the bay (Figure 6).

The results of the PCA showed the information which described the relationship between nutrient, physical and chemical parameter characteristics with the observation stations (Figure 7). Two main axes formed the relationship with a $78.33 \%$ accumulative characteristic values. It was the value that described the value of the information that could be obtained from the total information.

Based on the PCA analysis, three groups of the characteristics of the relationship between the environmental parameter and the stations of observation were formed. The first group was based on the characteristics of stations 2, 3 and 4. Those three stations were close to the two main characteristics, namely, the extended area of quite dense seagrass, and the location that was close to the big clusters of the floating fish cages.

Table 1. The environment and nutrient conditions of pegametan bay

\begin{tabular}{lll}
\hline Parameter & unit & Average (Sig. 0.05) \\
\hline Temperature & ${ }^{\circ} \mathrm{C}$ & $31.5 \pm 0.83$ \\
Conductivity & $\mathrm{mScm}$ & $43.6 \pm 0.44$ \\
Turbidity & $\mathrm{FNU}$ & $3 \pm 2.90$ \\
Salinity & PSU & $30.40 \pm 1.44$ \\
DO & $\mathrm{ppm}$ & $5.42 \pm 0.47$ \\
$\mathrm{COD}$ & $\mathrm{Mg} . \mathrm{L}^{-1}$ & $75.72 \pm 3.06$ \\
$\mathrm{ORP}$ & $\mathrm{mV}$ & $192.82 \pm 39.6$ \\
pH & & $8.24 \pm 0.70$ \\
\hline
\end{tabular}

High value in temperature, $\mathrm{COD}, \mathrm{ORP}$ and $\mathrm{pH}$ featured these areas. There were also specific characteristics of this group. Station 2 had high concentrations of COD and turbidity. Station 3 had high concentrations of Pt. Station 4 had the highest conductivity compared to the other stations. The causes were the location, which was close to the big floating fish cages, the deep waters and the color of the water that was always dark green. Its location was close to the floating fish cages and the place of transferring the fish cultivated in the fish cages onto the big sized shipping ships.

The second group was based on the characteristics of station 1 . The characteristics of station 1 are high in DO and salinity. . The station is located in the northern part of the bay, close to the coral reef. The substrate was white sand with seagrass growing on it. The third group was based on the characteristics of station 5, namely, a high concentration of nutrients $\mathrm{Nt}$ and $\mathrm{Pt}$. Its location was in the southern part of the bay. It was close to the floating fishnets and was $2-5$ $m$ in depth.

The analysis of similarity was calculated from the distance of the Euclidian between the physical and chemical parameter of the waters and the stations. The calculation results showed that there was a station grouping based on the characteristics of the environment. Stations 2 and 3 had the highest similarity value; the simi- 

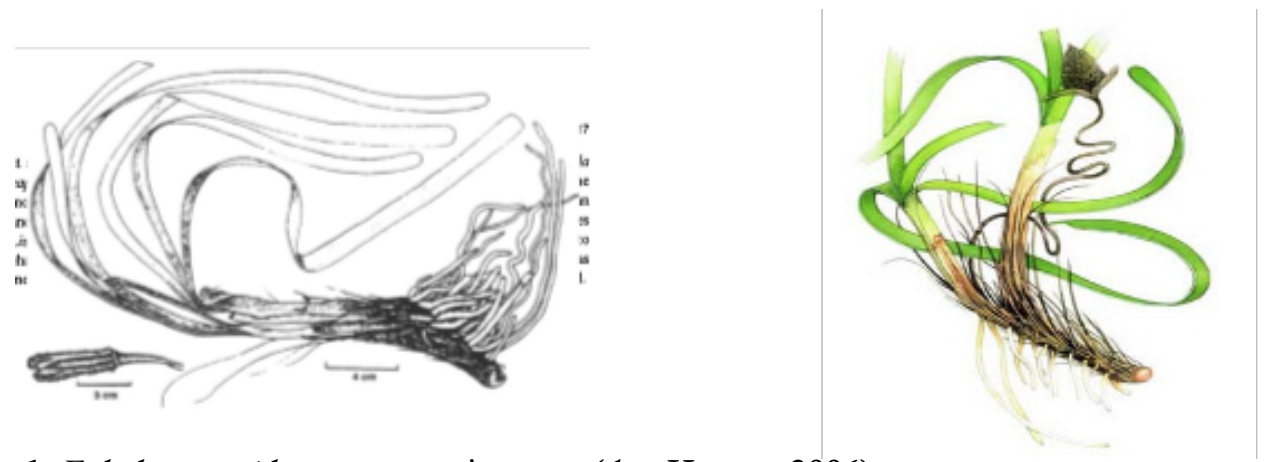

Figure 1. Enhalus acoroides a monotypic genus (den Hartog, 2006).
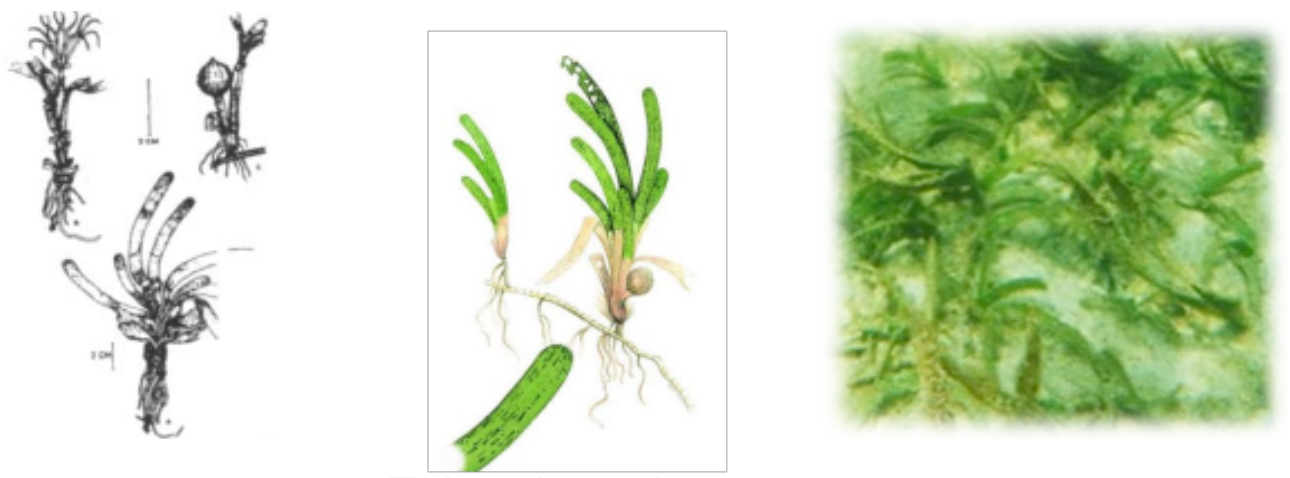

Figure 2. Thalassia hemprichii (den Hartog, 2006, research documentation).

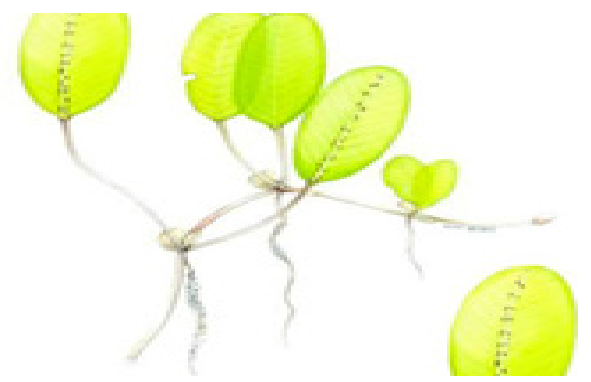

Figure 3. Halophila ovalis (den Hartog, 2006; SW, 2015)

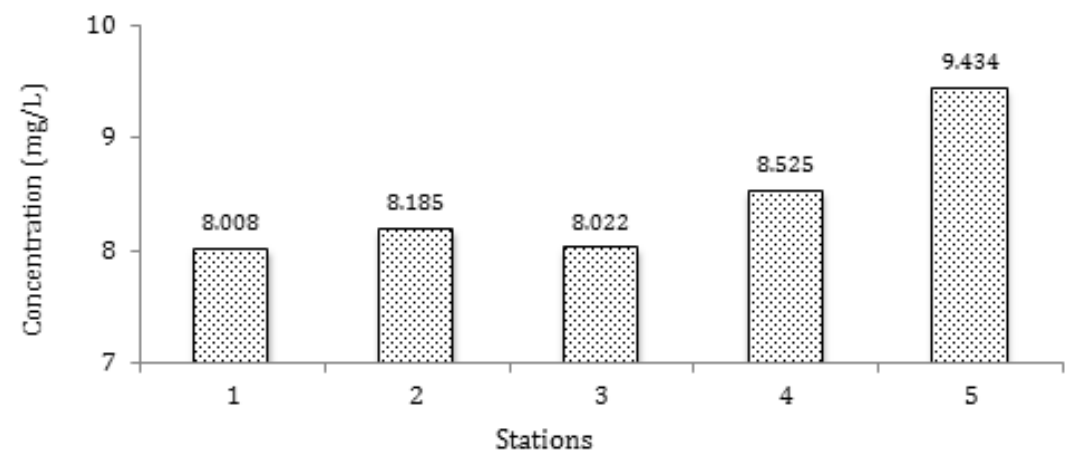

Figure 4. The concentration of total nitrogen in each observation station 


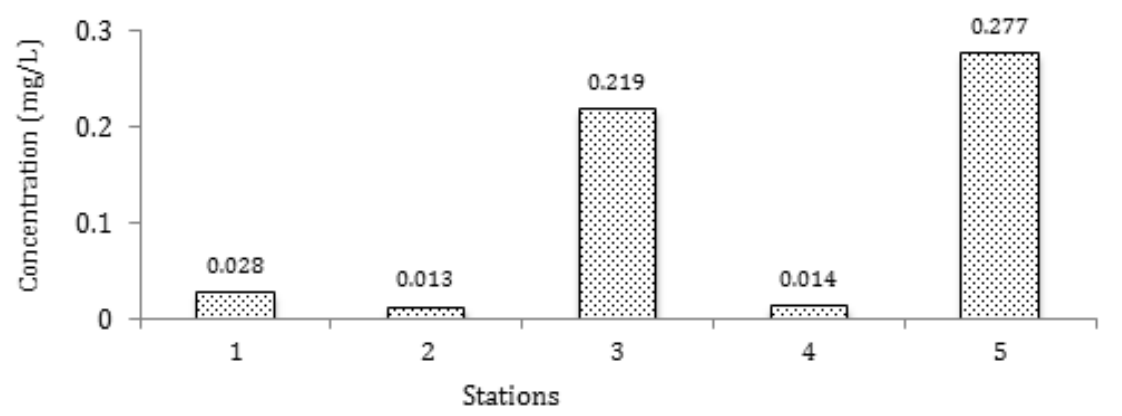

Figure 5. The concentration of total phosphor in each observation station

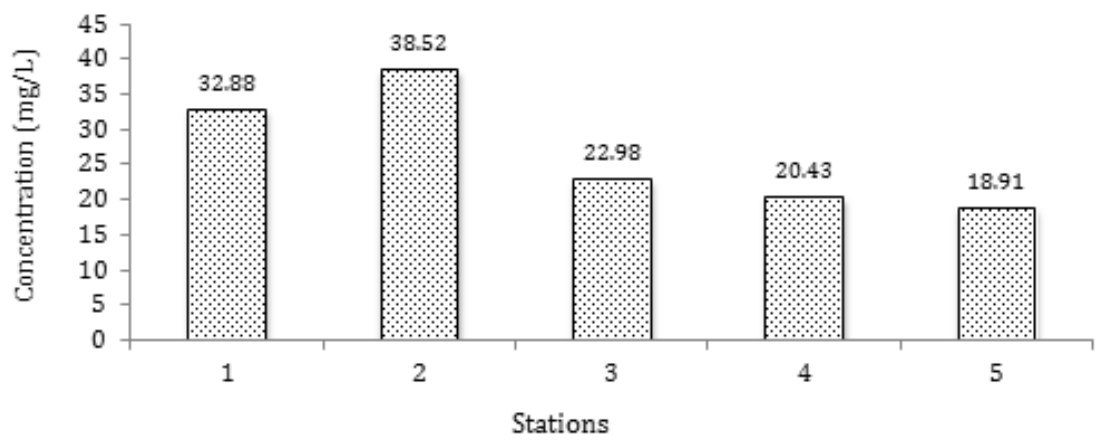

Figure 6. The concentration of doc in each observation station

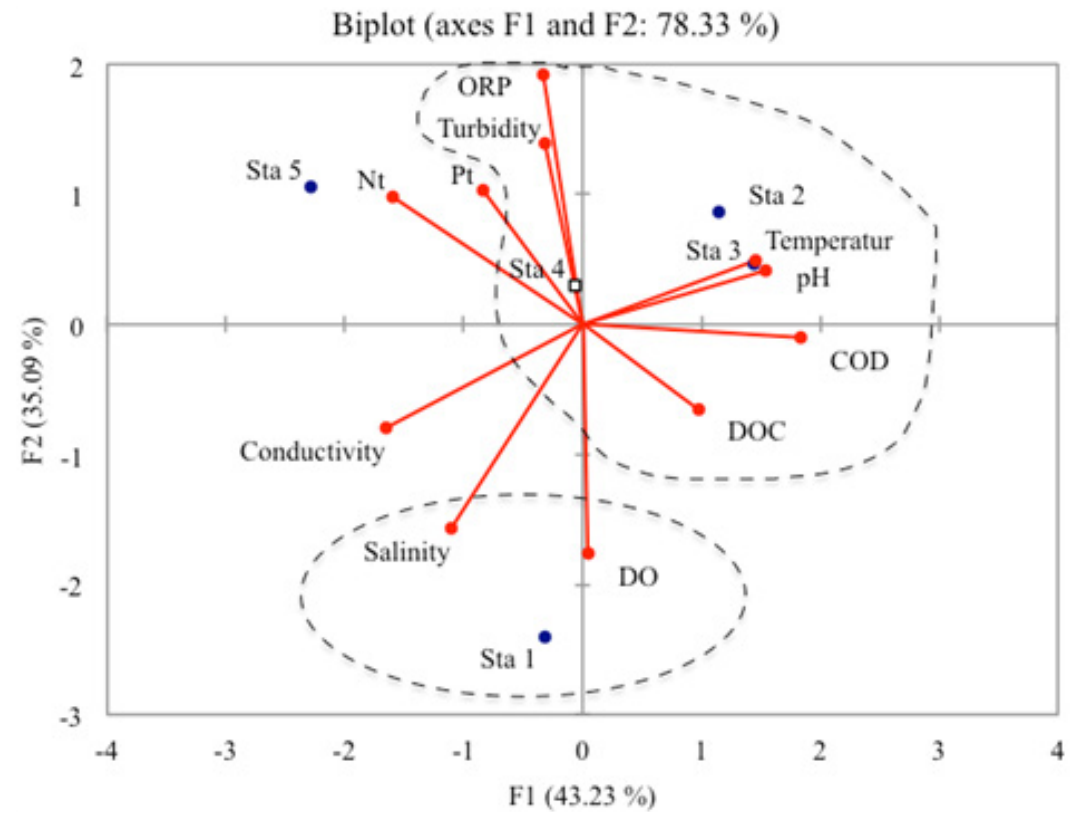

Figure 7. The Principles of component analysis of relationship between the chemical and physical characteristics of the waters and the nutrient with the observation station. Stations (sta).

larity was $84.73 \%$, followed by station 1 with a $79.73 \%$ similarity. Stations 4 and 5 formed their clusters with a $76.11 \%$ distance from cluster 1 . It means that the first three stations were similar to the northern part of the bay. Which, they are all close to the coral barrier reef and the big clus- ter of floating fish cages and were influenced by coverage of seagrass, particularly stations 1 and 3. Stations 4 and 5 were located in the southern part of the bay with seagrass growing on the substrates (Figure 8). 


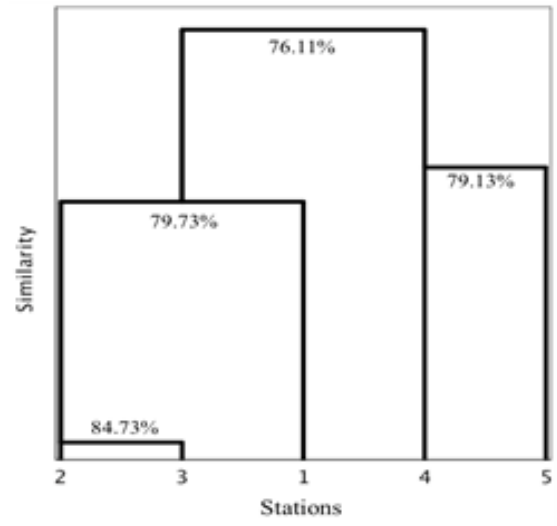

Figure 8. Dendogram of the inter-stations similarities based on the characteristics of the environment

\section{Phytoplankton abundance and composition}

There were three groups of phytoplankton identified, consist of dinoflagellates, diatoms and non-littoral. Diatoms dominated with a $74.56 \%$. The least abundant group was dinoflagellates with a $2.09 \%$. That value was even smaller than that of the abundance of the non-littoral group; that was $23.35 \%$. There were 27 species of phytoplankton identified at Pegametan Bay. They spread in five observation stations (Figure 9). The highest phytoplankton diversity was identified at station 4 with 23 species. Station 1 with 20 species was in the second place, station 2 with 16 species was in the third place, and station 3 with 14 species was in the fourth place, and the lowest phytoplankton diversity was identified at station 5 with 6 species.

There were merely 3 species of dinoflagellates identified at Pegametan Bay, consist of Ceratium sp., Dinophysis sp. and Protoperidinium sp. The abundance of those species was small, except Protoperidinium sp. (Figure 10). No dinoflagellates species was found in station 5. Ceratium sp. was only found in stations 1 and 2 and Dinophysis sp. was only identified in station 3 .

There were 18 species identified under the diatom group. Nitzschia sp had the highest abundance (Figure 11). The spread of this group was even; they were found in all observation stations. Among them, there were 6 species with abundance greater than $10^{4} \mathrm{cell} . \mathrm{mL}^{-1}$. There were 6 species identified under the non-littoral group (Figure 12). The identified phytoplanktons showed the characteristics of offshore and freshwater habitats. They consisted of two offshore phytoplanktons, three freshwater phytoplanktons and 1 was fresh water habitat cyanobacteria.
The correlations between the environmental characteristics with the phytoplankton composition and abundance

The results of correspondence analysis showed that the relationship between the phytoplankton abundance with the observation stations. The relationship was formed by two main axes (F1 and F2) with characteristic roots each $53.28 \%$ and $20.96 \%$. The information showing such a relationship was obtained from the accumulative characteristic root of $74.24 \%$ from the total information (Figure 13).

The results of the analysis led to four groupings of phytoplankton abundance towards stations. Group 1 was formed in station 1 with high abundance characteristic on the species of Flagillaria sp., Navicula sp., Diploneis sp., Odontela sp., Amphora sp., Coscinodesmus sp. (diatom). A high abundance was also shown by Oscillatoria sp., Synedra sp., Ankistrodesmus sp. and Licmophora sp. (non-littoral). A high abundance was merely found in 1 species of dinoflagellate, that is, Ceratium sp. This group had the highest species diversity; it had all types of phytoplanktons identified. Station 1 , as the indicator of this group, was situated close to the coral barrier reef in the northern part of the island.

Group 2 was formed based on station 2, characterised by high abundance characteristics of species Thalassiosira sp., Melosira sp., Asterionella sp., Coscinodiscus sp., Pleurosigma sp. dan Surirella sp. (diatom). A high abundance was also found in species Spirogyra sp. and Closterium sp. (non-littoral). This group was close to the big floating fish cages where baramundi and grouper were cultivated. The waters were deep enough whose depth ranged from $15-20 \mathrm{~m}$.

Group 3 was based on stations 3 and 4 with high abundance characteristics of species Nitzschia sp., Chaetoceros sp., Thalassiothrix sp., Ampiphora sp., Bacteriastrum sp. and Bacillaria sp. (diatom). A high abundance characteristic was also seen on Dinophysis sp. dan Protoperidinium sp. Stations 4 and 5 had the characteristics of this third group. The environment was shallow; it had white sand and seagrass growing close to each other.

The analysis of similarity was counted based on the Euclidean distance between the phytoplankton abundance and composition with stations. The similarity percentage was average and showed station grouping. Stations 3 and 5 had the highest similarity value with a similarity of $69.98 \%$, followed by station 1 with a similarity of $57.23 \%$. Stations 1 and 2 formed their clusters with a similarity of $44.45 \%$ from cluster 3 , mea- 
Gede Iwan Setiabudi, et al. / Biosaintifika 8 (3) (2016) 257-269

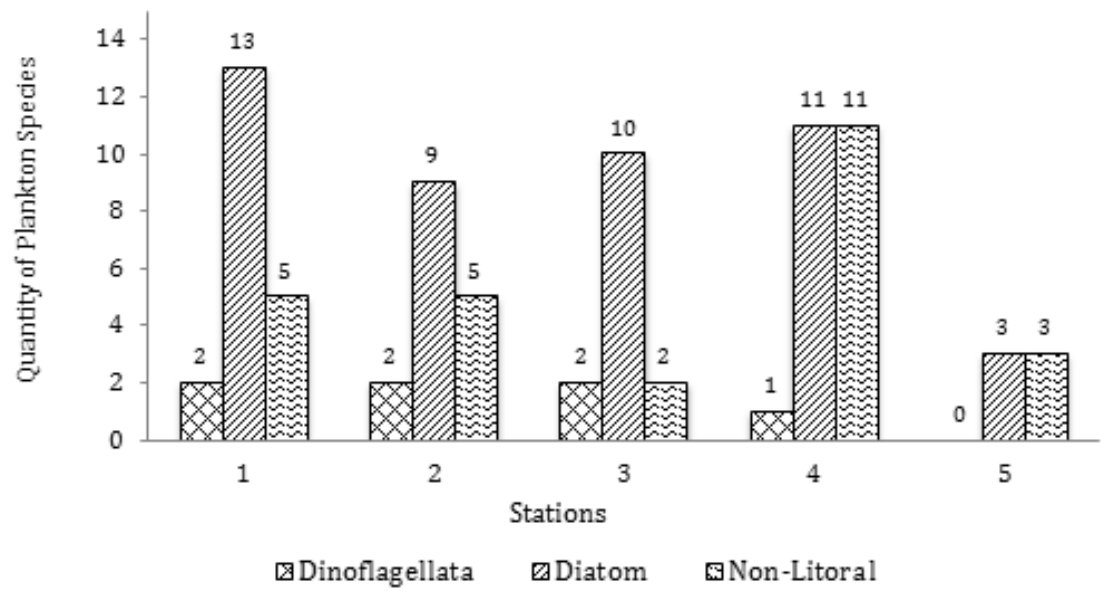

Figure 9. The spread of the identified phytoplankton species in each station

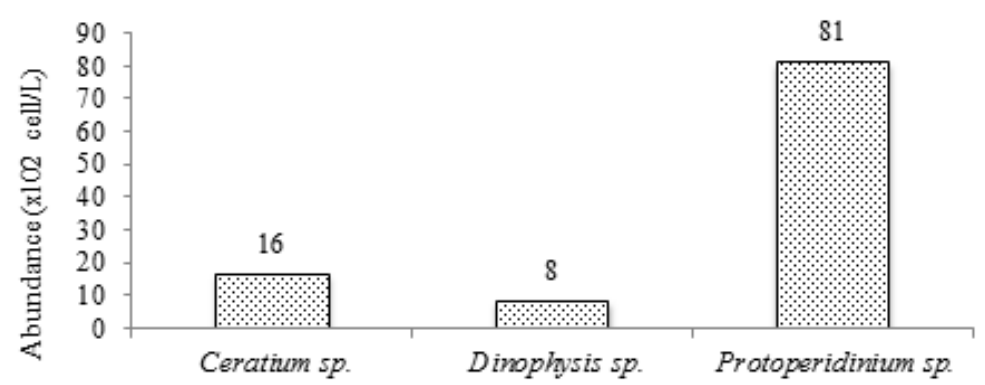

Figure 10. The total of dinoflagellates abundance at pegametan bay

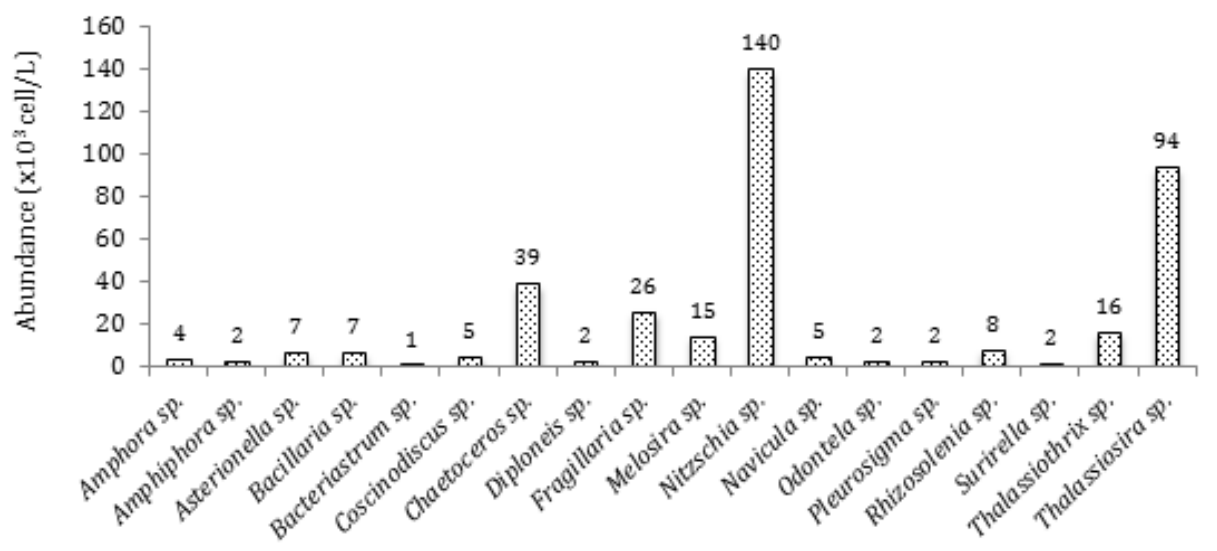

Figure 11. The total abundance of diatom at pegametan bay

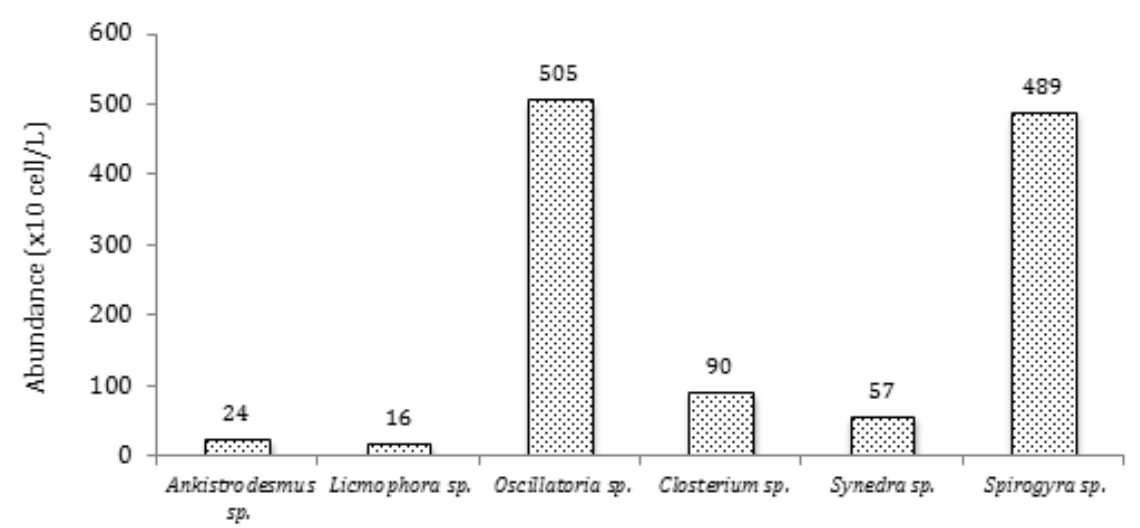

Figure 12. The total abundance of non-litoral phytoplankton at pegametan bay 


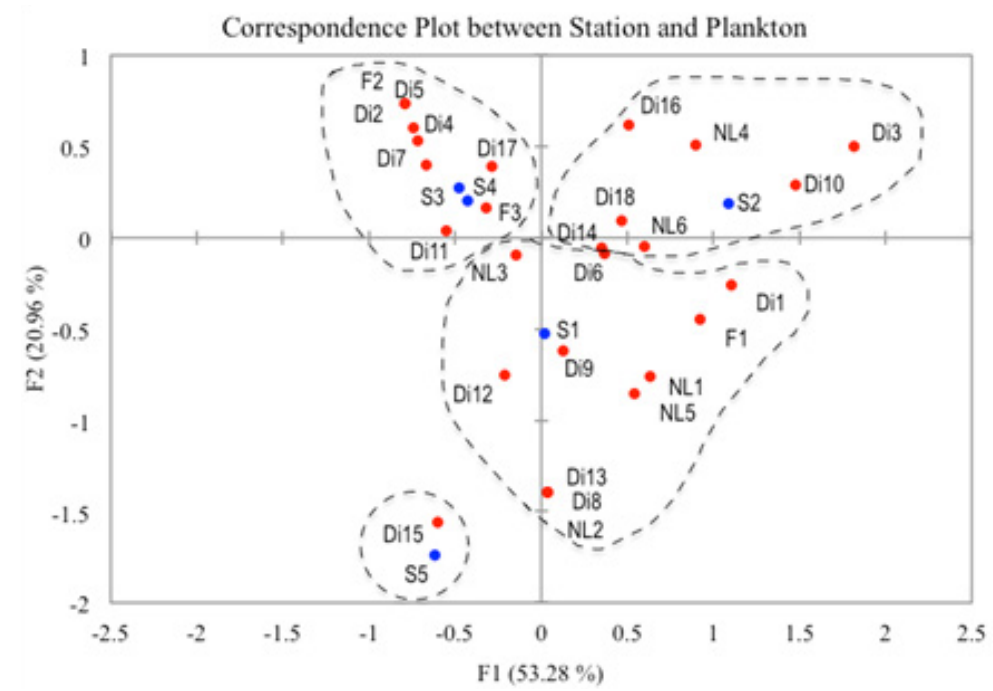

Figure 13. The correspondence analysis on the relationship between plankton abundance with characteristics of the station, In which: station marker (S1 s/d S5), Ceratium sp. (F1), Dinophysis sp. (F2), Protoperidinium (F3), Amphora sp. (Di1), Amphiphora sp. (Di2), Asterionella sp. (Di3), Bacillaria sp. (Di4), Bacteriastrum sp. (Di5), Coscinodiscus sp. (Di6), Chaetoceros sp. (Di7), Diploneis sp. (Di8), Fragillaria sp. (Di9), Melosira sp. (Di10), Nitzschia sp. (Di11), Navicula sp. (Di12), Odontela sp. (Di13), Pleurosigma sp. (Di14), Rhizosolenia sp. (Di15), Surirella sp. (Di16), Thalassiothrix sp. (Di17), Thalassiosira sp. (Di18), Ankistrodesmus sp. (NL1), Licmophora sp. (NL2), Oscillatoria sp. (NL3), Closterium sp. (NL4), Synedra sp. (NL5), Spirogyra sp. (NL6).

ning that the first three clusters showed similarity with dominant abundances of Nitzschia sp., Thalassiosira sp. and Oscillatoria sp. The cluster formed by station 1 and 2 showed similarity from high species abundance and composition.

Pegametan Bay was an area with an enclosed topography and intensive mariculture activities. The waters on the western side of the bay tended to be shallow because of the existence of the sand dune with seagrasses $E$. acoroides (dominant), T. hemprichii and $H$. ovalis growing on it. Such habitat was good for the growth of various planktons, including the epiphytes group. Borowtizka et al. (2006) stated that organisms that had high abundance and associated with seagrass ecosystem where plankton.

One of the main factors that influenced the plankton biomass at the estuary, particularly the seagrass ecosystem, was the existence of nutrients and the characteristics of the water environment. The pattern of the increase and decrease in the biomass was in line with the pattern shown by the seagrass biomass (Burkholder et al., 2007). The existence of fisheries activities contributed to the increase of nutrient content, which then yielded increasing number of plankton in waters (Wang et al., 2006; Price et al., 2015).

Baden et al. (2010) stated that the extended area of seagrass that underwent eutrophication condition contributed to the changes in the structures of mesograzers, epiphytic algae, and intermediate predators. Sara et al. (2011) discovered evidence that fisheries activities contributed to the rise of $\mathrm{N}$ and $\mathrm{P}$ concentration in the waters with radius $1-10 \mathrm{~km}$. The rise of the concentration of those two elements caused the rise of chlorophyll concentration in the waters significantly. It potentially changes the phytoplankton community structure in the waters ecosystem.

The comparison between the calculation results showed that phytoplankton variability was closely related to the environmental characteristics. Geographically, the locations of stations 3, 4 and 5 were close to the main characteristics, having seagrass growing on them and were situated in the western and southern parts of the bay. Station 1 was situated at the coral reef whose substrates were overgrown with seagrass. Station 2 was situated in deep waters and close to the mariculture activities.

Phytoplankton composition was dominated by diatoms, followed by non-littoral and dinoflagellates. It was related to the condition of the Pegametan Bay. The shape of the bay that was enclosed and looked like a big fish pond resulted in relatively uniform characteristics. Such characteristic resulted in the domination of diatom group (Ikpi et al., 2013; Akter et al., 2015). The enclosed environment and the many fisheries activities have limited space, not fluent water 
circulation and the organic residues made the environment more selective for the growth of phytoplankton species. Those factors triggered environmental changes and directly influenced the plankton variability (Xu et al., 2010; Sridhar et al., 2010; de Wit et al., 2012; Riniatsih et al., 2013).

The diatom group whose abundance was over $10^{4}$ cell. $\mathrm{mL}^{-1}$ consisted of 6 species, namely, Nitzschia sp., Thalassiosira sp., Chaetoceros sp., Flagillaria sp., Thalassiothrix sp. and Melosira sp. This group dominated the seashore area, particularly the areas which had mariculture activities in them (Garrido et al., 2014; George \& Atakpa, 2015; Akter et al., 2015). The group which had a low abundance consisted of 12 species. Nutrient concentration and light intensity were the factors which supported its survival in the seashore $(\mathrm{Xu}$ et al., 2010; Akter et al., 2015).

The morphology of diatom that was protected by the cell walls was an important factor to tolerate the environmental changes. This factor also enabled diatom to win the competition in occupying the living space and obtaining nutrients. The diatoms living in tropical areas had structures (spicules, seat, and hard cell walls) and chemical defense beneficial to survive in the environment that has numerous predators. The chemical defense was used to survive from the smaller predators, while the structural defense was used to survive from the bigger predators. Even the cell wall structure could absorb $30 \%$ of UVB radiation; hence, it could survive from high light exposure (McClintock et al., 2001; Paul et al., 2001; Karentz, 2001). The ability to absorb UV radiation was enabled by the mycrosporin-like amino acids (MAAs) compound in the cell of the phytoplankton. A few genus of Thalassiosira in Antartica and Thalassiosira sp. were known as having the ability to produce such a compound. That compound could absorb all long spectrums of UV waves. The higher the UV exposure from the sunlight, the higher the production of the compound (Karentz, 2001).

Protoperidinium sp dominated the abundance of dinoflagellates. The abundance of Ceratium sp. and Dinophysis sp. was relatively lower. Toha (2004) also managed to identify those three species at the seashores of Bangka Belitung and the South China Sea, though the abundance was relatively low. Gribble et al. (2007) found that many Protoperidinium sp. species were found in the areas close to the beach. The same was also found in this research. The highest abundance was found in stations 1 and 4, which were located close to the beach. Runyan (2014) found that there was a significant correlation between the three species in the waters of Puget Sound, Unites States of America. The environmental factors which influenced it w temperature, nutrients, and high light intensity.

Based on the observation results, the genera Protoperidinium was highly abundant and found in all observation stations, indicating that there were supporting factors. This genus has numerous species composition; hence, the naming was frequent without the species, the only Protoperidinium $\mathrm{sp}$. was used, indicating that it has numerous species. It is also known to have the ability to produce and chemocline kinetic and chemo orthokinetic chemoattractants, which function as a pre-finding mechanism. Those two attractants were the causes of the faster swimming speed and decreasing rotation of the predator cells around the preys. This fact enables this species to find preys effectively and efficiently.

Dinophysis sp. was one of the phytoplanktons included in the group of HABs. This species was merely found in station 3 , with a relatively low abundance $\left(815\right.$ cell. $\left.\mathrm{L}^{-1}\right)$. The high nutrient concentration caused its existeance in that stration; Pt (0.22 mg. $\left.\mathrm{L}^{-1}\right)$ and DOC (22.98 mg. $\left.\mathrm{L}^{-1}\right)$. Both nutrients were its energy source to survive and breed. Dinophysis sp. had the ability to produce metabolic dendrotoxin (DTX) and okadaic acid (OA). DTX was neurotoxic and phagotrophic. It killed the prey, predator, and competitors by lysing cells. A great number of OA compound led to DSP (diarrhetic shellfish Poisoning) on bigger organisms (Ignatiades \& Gotsis-Scretas, 2010). Wang et al. (2006) found out that this species was frequently found in the mollusc muscle and could cause DSP in humans. Based on the observation in the research location, station 3 was the main location to collect for various of shellfish.

The high existence of non-littoral phytoplanktons was also related to the mariculture activities at the Bay. There were six species identified; two of them had the offshores as the original habitat (Ankistrodesmus sp. and Licmophora sp.), three of them were freshwater phytoplankton species (Closterium sp., Synedra sp. and Spirogyra sp.) and one species was bacterioplankton (Oscilatoria sp.). The quantitative analysis showed that there was a close relationship between the phytoplankton with the DOC concentration, salinity, and DO. Those three factors enabled the phytoplanktons to adapt to the inappropriate environment. DOC was beneficial as nutrition source that could be directly absorbed by the phytoplanktons and high nutrition concentration was beneficial as the energy source for surviving and breeding. 
Karentz (2001) found out that Ankistrodesmus sp. had the ability to produce MAAs as a protection against UV radiation, similar to Thallassiosira sp.

Oscillatoria sp. belonged to cyanobacteria; the bacteria that could photosynthesize. Even though its morphology was filaments-shaped and fresh water was the original habitat, it was cosmopolitan genera. Its shape correlates with the abundance in calm water areas. Diatoms, corallites, and filament algae dominated the areas with calm waves. It tolerates the environmental condition in such a way that it could live everywhere, including in the seagrass ecosystem (Kendrick \& Burt, 1997; Pinckney \& Micheli, 1998; Koch et al., 2006). Hamisi et al. (2004) found out the high abundance of this species in the seagrass in the extended are of the Tanzania's seashore. DOC concentration, DO, and light intensity were important factors contributing to the existence of the species. Many reports also mentioned that the abundance of this species was also high in mariculture areas (Yang et al. 2014; George and Atakpa 2015; Akter et al., 2015). Exact compositions of seagrass ecosystem, mariculture areas and the calm water condition at Pegametan Bay resulted in a high abundance of Oscillatoria sp.

The Oscillatoriaceae family was known as being rich in a few secondary metabolites, including antibiotic lipid compounds. The highest abundance of Oscillatoria sp. was seen in stations 1 and 4 . The results of CA and PCA showed the highest $\mathrm{DO}$ concentration in those two stations. It was related to the characteristic of Oscillatoria sp. which was attractive to high DO. Amsler \& Iken (2001) stated that the attractants of that species were carbon dioxide, oxygen, and bicarbonate. It confirms that the abundance of Oscillatoria sp. was positively correlated with $\mathrm{DO}$ concentration in the waters. It was also known that this species was capable of surviving from the high UV radiation because it could form secondary metabolite compound named biopterin glucoside (BG). Such a metabolite was produced in a great amount as it got more exposed to the sunlight (Karentz, 2001).

Mariculture business at the sea in the forms of intensive floating fish cages needed fresh water for many purposes. Fresh water was used to disinfect, and the fish infected with parasites and to fulfill the needs of the workers. It was then the source of fresh water phytoplanktons. The phytoplanktons whose original habitat was offshore came from fishing boats and were carried by ballast water or stucked to the hull. Garrido et al. (2014) also found that many non-littoral species were also found at the enclosed mariculture area at Corsica, in the Mediterranean Sea.
The non-littoral phytoplanktons as nonindigenous species showed that all mariculture activities gave pressure on the bay environment. Nutrient adding as the consequence of the agriculture and shipping activities resulted in high non-littoral phytoplankton abundance. It resulted in the changes in the phytoplankton community structures. Helsinki Commision (2009) in his report mentioned that aquaculture activities and the supporters gave pressure on the environment. Various aspects such as water quality change, organism community change, topic and the emergence of non-indigenous species emerged.

\section{CONCLUSION}

The phytoplankton community structure, in this case, the composition and abundance at Pegametan Bay were influenced by the environmental characteristic, that was enclosed, and the mariculture activities. At the Bay, 27 species of phytoplankton could be identified which could be divided into 3 groups. They were the diatom group which consisted of 18 species with a $74.56 \%$ abundance, the non-littotal group which consisted of 6 species with a $23.35 \%$ abundance and the dinoflagellate group which consisted of 3 species with a $2.09 \%$ abundance.

Phytoplankton abundance which was over $10^{4}$ cell. $\mathrm{L}^{-1}$ was found in two groups, diatom, and non-littoral groups. Diatom group consisted of 6 species Nitzschia sp., Thalassiosira sp., Chaetoceros sp., Flagillaria sp., Thalassiothrix sp. and Melosira sp. The non-littoral group consisted of Oscillatoria sp. and Spirogyra sp. The abundance of those species indicated high growth and algae bloom. Besides, a harmful algae (HABs), Dinophysis sp., was also identified.

\section{REFERENCES}

Akter, S., Rahman, M. M, \& Akter, M. (2015). Composition and Abundance of Phytoplankton Population in Fish Ponds of Noakhali District, Bangladesh. American-Eurasian Journal of Agriculture and Environmental Science, 15(11), 21432148.

Amsler, C. D., \& Iken, K. B. (2001). Chemokinesis and chemotaxis in marine bacteria and algae. In J. B. McClinTOCk, \& B. J. Baker (Eds.), Marine chemical ecology (pp. 413-430). CRC Press.

Baden, S., Bostrom, C., Tobiasson, S., Arponen, H., \& Moksnes, P. O. (2010). Relative Importance of Trophic Interactions and Nutrient Enrichment in Seagrass Ecosystems: A broad-scale Field Experiment in the Baltic-Skagerrak Area. Limnology and Oceanography, 55(3), 1435-1448. 
Bengen, D. G. (2000). Tehnik Pengambilan Contoh dan Analisis Data Biofisik Sumberdaya Pesisir. Bogor: IPB Press.

Borowitzka, M. A., Lavery, P. S., \& van Keulen, M. (2006). Epiphyte of Seagrasses. Larkum, A. W. D., Orth, R. J., \& Duarte, C. M., editor. Amsterdam: Springer.

Burkholder, J. M., Tomasko, D. A., \& Thouchette, B. W. (2007). Seagrass and Eutrophication. Journal of Marine Biology and Ecology, 350(1), 46-72.

de Witt, R., Troussellier, M., Courties. C., BuffanDubau, E., \& Lemaire, E. (2012). Short-term Interactions between Phytoplankton and Intertidal Seagrass Vegetation in a Coastal Lagoon (Bassin d'Arcachon, SW France). Hydrobiologia, 699(1), 55-68.

den Hartog, C. (2006). Taxonomy and Biogeography of Seagrasses. Larkum, A. W. D., Orth, R. J., \& Duarte, C. M., editor. Netherlands: Springer.

Fachrul, M. F. (2007). Metode Sampling Bioekologi. Jakarta: Bumi Aksara.

Garrido, M., Koeck. B., Goffart, A., Collignon, A., Hecq, J. H., Agostini, S., Marchand, B., Lejeune, P., \& Pasqualini, V. (2014). Contrasting Pattern of Phytoplankton Assembalges in Two Coastal Ecosystems in Relation to Enviromental Factors (Corsica, NW Meditteranian Sea). Diversity, 6, 296-322.

George, U. U., \& Atakpa, E. O. (2015). Diversity and Species Composition of Periphyton in a Tropical Earthen Pond in South Eastern Nigeria. World Rural Observation, 7(4), 65-70.

Gribble, K. E., Nolan, G., \& Anderson, D. M. (2007). Biodiversity, Biogeography and Potential Trophic Impact of Protoperidinium spp. (Dinophyceae) off the Shoutwestern Coast of Ireland. Journal of Plankton Research, 29(2), 931-947.

Hamisi, M. I., Lyimo, T. J., \& Muruke, M. H. S. (2004). Cyanobacterial Occurrence and Diversity in Seagrass Meadows in Coastal Tanzania. Western Indian Journal of Marine Science, 3(2), 113-122.

Hanafi A. (2004). Penelitian Lingkungan Budidaya di Teluk Sumberkima dan Teluk Sepi. Laporan Balai Baser Riset Perikanan Budidaya laut (BBRPBL) Gondol.

Helsinki Commision (Baltic Marine Environment Protection Commission). (2009). Biodiversity in the Baltic Sea: An Integrated Thematic Assesment on Biodiversity and Nature Conservation in the Baltic Sea. Baltic Sea Proceedings. 116B: 92-135.

Ignatiades, L., Gotsis-Skretas, O. (2010). A Review on Toxic and Harmful Algae in Greek Coastal Waters (E. Mediterranean Sea). Toxin, 2(4), 1019-1037.

Ikpi, G. U., Offem, B. O., Okey, I. B. (2013). Plankton Distribution and Diversity in Tropical Earthen Fish Ponds. Environmetal and Natural Resources Research, 3(3), 45-51.

Kendrick, G. A., \& Burt, J. S. (1997). Seasonal Changes in Epiphytic Macroalgae Assemblages be- tween Offshore Exposed and Inshore Protected Posidonia sinuosa Seagrass Meadows, Western Australia. Botanica Marina, 40(1-6), 77-85.

Kennish, M. J. (2010). Barnegat Bay-Little Egg Harbor: Eutrophication Update. Presentation at NJ Water Monitoring Council Meeting.

Karentz, D. (2001). Chemical Defenses of Marine Organisms Against Solar Radiation Exposure: UV-Absorbing Mycosporine-Like Amino Acids and Scytonemin. McClintock, J. B., \& Baker, B. J., editor. Florida: CRC Press LLC.

Koch, E. W., Ackerman, J.D., Verdiun, J., \& van Keulan, M. (2006). Fluid Dynamics in Seagrass Ecology from Molecules to Ecosystems. Larkum, A. W. D., Orth, R. J., \& Duarte, C. M., editor. Netherlands: Springer.

Kuo, J., \& den Hartog, C. (2006). Seagrass Taxonomy and Identification Keys. Di dalam: Short, F. T., Coles, R. G., editor. Amsterdam: Elsevier Science BV. 31-58.

Marba, N., Holmer, M., Gacia, E., \& Baron, C. (2006). Seagrass Beds and Coastal Biogeochemistry. Larkum, A. W. D., Orth, R. J., \& Duarte, C. M., editor. Amsterdam: Springer.

McClintock. J. B., Baker, B. J., \& Steinberg, D. K. (2001). The Chemical Ecology of Invertebrate Meroplankton and Holoplankton. McClintock, J.B., Baker, B. J., editor. Florida: CRC Press LLC.

Paul, V. J., Cruz-Rivera, E., \& Thacker, R. W. (2001). Chemical Mediation of Macroalgal-Herbivore Interactions: Ecological and Evolutionary Perspectives. McClintock, J. B., \& Baker, B. J., editor. Florida: CRC Press LLC.

Pinckney, J. L., \& Micheli, F. (1998). Microalgae on Seagrass Mimics: Does Epiphyte Community Structure Differ from Live Seagrasses?. Journal of Experimetal Marine Biology and Ecology, 221(1). 59-70.

Price, C., Black, K. D., Hargrave, B.T., \& Morris Jr, J. A. (2015). Marine Cage Culture and the Environment: Effects on Water Quality and Primary Production. Aquaculture Environment Interactions, 6(2), 151-174.

Riniatsih, I., Widyaningsih, Rejeki, S., Endrawati, H., Agus, E. L. (2013). Kelimpahan Fitoplankton di Padang Lamun Buatan. Ilmu Kelautan, 18(2), 8490.

Runyan, J. S. (2014). Seasonal Variation of the Genus Dinophysis within Puget Sound, Washington: Understanding Harmful Algal Blooms Through Species Identification. Tesis. Postgraduate Program of The Evergreen State College. Washington.

Sara, G., Martire, M. L., Sanfilippo, M. L., Pulicano, G., Cortese, G., Mazola, A., Manganaro, A., \& Pusccedu, A. (2011). Impacts of Marine Aquaculture at Large Spatial Scales: Evidences From N and P Catchment Loading and Phytoplankton Biomass. Marine Environmental Research, 71(5), 317-324.

Setiabudi, G. I. (2007). Karakteristik Fisika Kimia 
Gede Iwan Setiabudi, et al. / Biosaintifika 8 (3) (2016) 257-269

Sedimen Teluk Kaping, Bali: Kaitannya dengan Komposisi dan Kelimpahan Bakteri. Tesis. Bogor: Institut Pertanian Bogor.

Sridhar, R., Thangaradjou, T., \& Kannan, L. (2010) Spatial and Temporal Variations in Phytoplankton in Coral Reef and Seagrass Ecosystems of The Palk Bay, Southeast Coast of India. Journal of Environmental Biology, 31(5), 765-771.

[SW] Seagrass-Watch. (2015). Tropical Seagrass Identification. Australia. Seagrass-Wacth HQ.

Toha, H. (2004). Kelimpahan Plankton di Perairan Bangka-Belitung dan Laut China Selatan, Sumatra, MeiJuni 2002. Makara Sains, 8(3), 96-102.

Wang. J., Qin, Y., Liu, C., Chen, X., Xu, R. (2006). Dinophysis spp. The Abundance, Distribution, and The Toxicity of DSP in East China Sea. Catatan Penelitian.

Xu, H., Min, G. S., Choi, J. K., Al-Rasheid, K. A. S., Lin, X., \& Zhu, M. (2010). Temporal Dynamic of Phytoplankton Communities in a Semi-enclosed Mariculture pond and Their Responses to Environmental Factors. Chinese Journal of Oceanography and Limnology. 28(2), 295-303.

Yamaji, I. (1982). Illustrations of the Marine Plankton of Japan. Tokyo: Hoikusha Publication Co.

Yang, D., Shan, X., \& Liu, S. (2014). Bacterioplankton, Picoeukaryotes and Synechococcus Distribution Associated with Seagrass in South Coast of Hainan Island, China. Natural Resources, 5, 454-461. 